\title{
Interaction between antibiotics and non-conventional antibiotics on bacteria
}

\author{
Gyöngyi Gunics a,*, Noboru Motohashi ${ }^{\mathrm{b}}$, Leonard Amaral ${ }^{\mathrm{c}}$, Sandor Farkas ${ }^{\mathrm{d}}$, \\ Joseph Molnár ${ }^{a}$ \\ a Department of Microbiology, Albert Szent-Gybrgyi Medical University, Szeged, Dóm tér 10, H-6720 Hungary \\ ${ }^{\mathrm{b}}$ Meiji Pharmaceutical University, Kiyose, Tokyo, Japan \\ ${ }^{\mathrm{c}}$ Division of Mycobacteriology, The Institute of Hygiene and Tropical Medicine, Lisbon, Portugal \\ ${ }^{\mathrm{d}}$ Environmental Microbiological Research Group of the Hungarian Academy of Sciences, Godollo University of Agricultural Sciences, \\ Godollo, Hungary
}

\begin{abstract}
The individual activity of antibiotics such as ampicillin, tetracycline, erythromycin and gentamicin in combination with compounds known to modify bacterial resistance to given antibiotics was studied using the checkerboard method. The combination of promethazine with either ampicillin, tetracycline or erythromycin or the combination of methylene blue and erythromycin produced significant synergistic activity against Escherichia coli. Verapamil, however, in combination with ampicillin reduced the activity of ampicillin against E. coli. Combinations of clomipramine with either tetracycline or erythromycin, promethazine and erythromycin or verapamil and ampicillin were synergistic against Staphylococcus epidermidis that was resistant to these antibiotics. The only synergy against Pseudomonas aeruginosa was shown by the combination of methylene blue and gentamicin. (C) 2000 Elsevier Science B.V. and International Society of Chemotherapy. All rights reserved.
\end{abstract}

Keywords: Synergism; Resistance modifiers; Antibiotics

\section{Introduction}

Tricyclic neuroleptics and antidepressants have direct activity against bacteria [1-5] and mycobacteria [6], enhance the activity of specific antibiotic [7-10], reverse the natural resistance of specific bacteria to given antibiotics $[8,9,11]$, promote the elimination of plasmids from Escherichia coli [4,12], and inhibit transport functions of the plasma membrane to given antibiotics $[11,13]$. Inhibition of plasma membrane based efflux pumps have been observed with a variety of phenothiazines and their derivatives [5].

The enhancement of antibiotic activity or the reversal of antibiotic resistance by non-conventional antibiotics affords the classification of these compounds as

\footnotetext{
* Corresponding author. Tel.: + 36-62-455115; fax: + 36-62455113 .
}

modifiers of antibiotic activity [11,13-15]. Verapamil (VP) is a well known modifier of antibiotic resistance. This compound, as well as the phenothiazinesmethylene blue and promethazine (PZ), and the structurally related clomipramine were tested for their potential separate interaction with four representative antibiotics-ampicillin, erythromycin, gentamicin and tetracycline against E. coli, Staphylococcus epidermidis and Pseudomonas aeruginosa using the checkerboard method [16].

\section{Materials and methods}

\subsection{Antibiotics}

Ampicillin (AMP) (Beecham Research Laboratories, UK), tetracycline (TET) and gentamicin (GENT) (Chinoin, Budapest, Hungary), erythromycin (ERY) (Richter Gedeon Rt, Budapest, Hungary). 


\subsection{Modifiers of antibiotic activity}

Promethazine (PZ) (Pipolphen EGIS, Budapest, Hungary), methylene blue (MB) (Reanal, Budapest, Hungary), clomipramine (CP, Anaphranil) (Ciba, Beigy, Basel, Switzerland), verapamil (VP) (Chinoin, Budapest, Hungary).

\subsection{Checkerboard method}

The checkerboard method [17] is the technique used most frequently to assess antimicrobial combinations in vitro. Dilutions of the antimicrobials and resistance

Table 1

MIC of antibiotics and the effect of combinations with resistance modifiers against $E$. coli

\begin{tabular}{|c|c|c|}
\hline $\begin{array}{l}\text { Antibiotics + resistance } \\
\text { modifiers }\end{array}$ & $\mathrm{MIC}\left(\mathrm{mg}^{-1}\right)$ & $\begin{array}{l}\text { Type of interac- } \\
\text { tion }\end{array}$ \\
\hline Promethazine (PZ) & 128 & \\
\hline Methylene blue (MB) & 400 & \\
\hline Clomipramine (CP) & 64 & \\
\hline Verapamil (VP) & $>1250$ & \\
\hline Ampicillin (AMP) & 4 & \\
\hline$+\mathrm{PZ}$ & $\begin{array}{l}\operatorname{AMP}(1)+\mathrm{PZ} \\
(16)\end{array}$ & Synergy \\
\hline$+\mathrm{MB}$ & $\begin{array}{l}\mathrm{AMP}(1)+\mathrm{MB} \\
(25)\end{array}$ & Synergy \\
\hline$+\mathrm{CP}$ & $\begin{array}{l}\operatorname{AMP}(1)+\mathrm{CP} \\
(16)\end{array}$ & Synergy \\
\hline$+\mathrm{VP}$ & $\begin{array}{l}\operatorname{AMP}(1)+V P \\
(>1250)\end{array}$ & Antagonism \\
\hline Tetracycline (TET) & 1 & \\
\hline$+\mathrm{PZ}$ & $\begin{array}{l}\text { TET }(0.25)+\mathrm{PZ} \\
(32)\end{array}$ & Synergy \\
\hline$+\mathrm{MB}$ & $\begin{array}{l}\text { TET }(0.50)+M B \\
(32)\end{array}$ & Additive \\
\hline$+\mathrm{CP}$ & $\begin{array}{l}\text { TET }(0.25)+C P \\
(32)\end{array}$ & Additive \\
\hline$+\mathrm{VP}$ & $\begin{array}{l}\text { TET }(1)+\mathrm{VP}(> \\
1250)\end{array}$ & Indifferent \\
\hline Erythromycin (ERY) & 8 & \\
\hline$+\mathrm{PZ}$ & $\begin{array}{l}\text { ERY (1)+PZ } \\
(32)\end{array}$ & Synergy \\
\hline$+\mathrm{MB}$ & $\begin{array}{l}\text { ERY (2)+MB } \\
(50)\end{array}$ & Snergy \\
\hline$+\mathrm{CP}$ & $\begin{array}{l}\text { ERY (4) +CP } \\
(32)\end{array}$ & Additive \\
\hline$+\mathrm{VP}$ & $\begin{array}{l}\mathrm{ERY}(4)+\mathrm{VP}(> \\
1250)\end{array}$ & Additive \\
\hline Gentamicin (GENT) & 1 & \\
\hline$+\mathrm{PZ}$ & $\begin{array}{l}\text { GENT }(0.5)+\text { PZ } \\
(64)\end{array}$ & Additive \\
\hline$+\mathrm{MB}$ & $\begin{array}{l}\text { GENT }(0.5)+ \\
\text { MB }(25)\end{array}$ & Additive \\
\hline$+\mathrm{CP}$ & $\begin{array}{l}\text { GENT }(0.5)+\text { CP } \\
\text { (32) }\end{array}$ & Additive \\
\hline$+\mathrm{VP}$ & $\begin{array}{l}\text { GENT (1)+VP } \\
(>1250)\end{array}$ & Indifferent \\
\hline
\end{tabular}

modifiers were made in minimal tryptone yeast (MTY) broth for the evaluation of interactions and antibacterial effects. The results of the combined effect of antibiotics and interpreted modifiers were evaluated for synergism, additive, indifference or antagonism. Three bacterial strains were tested by the microdilution checkerboard technique. Dilutions from the logarithmicgrowth phase of bacterial cultures were prepared and distributed into microtiter trays containing varying concentrations of the different drugs. The final inoculum size per microtiter well was approximately $10^{5}$ colony forming unit $(\mathrm{CFU}) / \mathrm{ml}$. The inoculated trays were incubated at $37^{\circ} \mathrm{C}$ for a period of $24 \mathrm{~h}$, and then evaluated for bacterial growth. In order to evaluate the activity of combinations of drugs, fractional inhibitory concentration (FIC) indices were calculated as $\mathrm{FIC}_{\mathrm{A}}+$ $\mathrm{FIC}_{\mathrm{B}}$, where $\mathrm{FIC}_{\mathrm{A}}$ and $\mathrm{FIC}_{\mathrm{B}}$ represent the minimum concentrations that inhibited the bacterial growth for drugs $\mathrm{A}$ and $\mathrm{B}$, respectively.

$\mathrm{FIC}_{\mathrm{A}}=\frac{\mathrm{MIC}_{\mathrm{A}} \text { combination }}{\mathrm{MIC}_{\mathrm{A}} \text { alone }}$
$\mathrm{FIC}_{\mathrm{B}}=\frac{\mathrm{MIC}_{\mathrm{B}} \text { combination }}{\mathrm{MIC}_{\mathrm{B}} \text { alone }}$

A mean FIC index was calculated based on the following equation: $\mathrm{FIC}_{\text {index }}=\mathrm{FIC}_{\mathrm{A}}+\mathrm{FIC}_{\mathrm{B}}$ and the interpretation made as follows: synergistic $(<0.5)$, additive $(0.5-1.0)$, indifferent $(>1)$, or antagonistic $(>4.0)$.

\subsection{Bacterial strains}

Escherichia coli K12 LE 140 tsx, str, $\Delta$ lac, su', $\lambda^{\mathrm{r}}$, $\mathrm{mal}^{-}$, Pseudomonas aeruginosa and Staphylococcus epidermidis were clinical isolates. The bacterial strains were cultured in MTY broth [18].

\section{Results}

The strain of $E$. coli used in this study was susceptible to ampicillin, tetracycline, erythromycin and gentamicin with MIC's of 4.0, $1.0,8.0$ and $1.0 \mathrm{mg} / 1$ respectively. This strain was resistant to promethazine $(\mathrm{MIC}=128 \mathrm{mg} / \mathrm{l})$, methylene blue $(400 \mathrm{mg} / \mathrm{l})$, clomipramine $(64 \mathrm{mg} / \mathrm{l})$ and verapamil $(1250 \mathrm{mg} / \mathrm{l})$.

Table 1 shows the results of the combinations of antibiotics and the resistance modifiers, at or below their MIC. Promethazine, methylene blue or clomipramine by themselves have limited inhibitory activity against $E$. coli. They however, enhance the activity of ampicillin at concentrations that was not inhibitory. Synergism was not observed with combinations of ampicillin and verapamil. At concentrations equal to each MIC, the result was antagonism. The 
Table 2

MIC of antibiotics and the effect of combinations with resistance modifiers against $S$. epidermidis

\begin{tabular}{|c|c|c|}
\hline $\begin{array}{l}\text { Antibiotics + resistance } \\
\text { modifiers }\end{array}$ & $\mathrm{MIC}\left(\mathrm{mg}^{-1}\right)$ & $\begin{array}{l}\text { Type of interac- } \\
\text { tion }\end{array}$ \\
\hline Promethazine (PZ) & 64 & \\
\hline Methylene blue (MB) & 400 & \\
\hline Clomipramine (CP) & 64 & \\
\hline Verapamil (VP) & $>1250$ & \\
\hline Ampicillin (AMP) & 256 & \\
\hline$+\mathrm{PZ}$ & $\begin{array}{l}\mathrm{AMP}(128)+\mathrm{PZ} \\
(32)\end{array}$ & Additive \\
\hline$+\mathrm{MB}$ & $\begin{array}{l}\mathrm{AMP}(128)+\mathrm{MB} \\
(25)\end{array}$ & Additive \\
\hline$+\mathrm{CP}$ & $\begin{array}{l}\operatorname{AMP}(64)+\mathrm{CP} \\
(32)\end{array}$ & Additive \\
\hline$+\mathrm{VP}$ & $\begin{array}{l}\text { AMP }(256)+\mathrm{VP} \\
(>1250)\end{array}$ & Indifferent \\
\hline Tetracycline (TET) & 32 & \\
\hline$+\mathrm{PZ}$ & $\begin{array}{l}\text { TET (4) + PZ } \\
(16)\end{array}$ & Synergy \\
\hline$+\mathrm{MB}$ & $\begin{array}{l}\text { TET }(16)+\mathrm{MB} \\
(50)\end{array}$ & Additive \\
\hline$+\mathrm{CP}$ & TET (8) + CP (8) & Synergy \\
\hline$+\mathrm{VP}$ & $\begin{array}{l}\text { TET (32)+VP } \\
(>1250)\end{array}$ & Indifferent \\
\hline Erythromycin (ERY) & 64 & \\
\hline$+\mathrm{PZ}$ & $\begin{array}{l}\text { ERY }(16)+P Z \\
(16)\end{array}$ & Synergy \\
\hline$+\mathrm{MB}$ & $\begin{array}{l}\text { ERY (16)+MB } \\
(50)\end{array}$ & Additive \\
\hline$+\mathrm{CP}$ & ERY (2) + CP (4) & Synergy \\
\hline$+\mathrm{VP}$ & $\begin{array}{l}\text { ERY (64)+VP } \\
(>1250)\end{array}$ & Indifferent \\
\hline Gentamicin (GENT) & 0.5 & \\
\hline$+\mathrm{PZ}$ & $\begin{array}{l}\text { GENT }(0.25)+ \\
\text { PZ (16) }\end{array}$ & Additive \\
\hline$+\mathrm{MB}$ & $\begin{array}{l}\text { GENT }(0.25)+ \\
\text { MB }(25)\end{array}$ & Additive \\
\hline$+\mathrm{CP}$ & $\begin{array}{l}\text { GENT }(0.25)+ \\
\text { CP (32) }\end{array}$ & Additive \\
\hline$+\mathrm{VP}$ & $\begin{array}{l}\text { GENT }(0.5)+\text { VP } \\
(>1250)\end{array}$ & Indifferent \\
\hline
\end{tabular}

combinations of resistance modifiers and tetracycline, erythromycin, gentamicin gave varied responses. Of the four resistance modifiers employed, synergism was observed with promethazine in combination with tetracycline and erythromycin, and with the combination of methylene blue and erythromycin.

The synergism shown by promethazine against $S$. epidermidis was much less than that against E. coli (Table 2). Promethazine acted synergistically with tetracycline and erythromycin. Clomipramine and erythromycin was also synergistic against $S$. epidermidis. Against Pseudomonas aeruginosa, the only synergy was seen with methylene blue and gentamicin (Table 3).

\section{Discussion}

The direct antibacterial activity of phenothiazines against susceptible bacteria has been studied over many years $[12,19]$. The use of these compounds for the management of bacterial infections has not been attempted because the concentrations that inhibit bacterial growth in vitro [15] are not clinically achievable. Some of these compounds are also known to produce serious side effects. Nevertheless, administration of clinical doses of the phenothiazine, promethazine as an adjuvant to conventional antibiotic therapy for difficult paediatric bacterial infections has yielded significant

Table 3

MIC of antibiotics and the effect of combinations with resistance modifiers against Pseudomonas aeruginosa

\begin{tabular}{|c|c|c|}
\hline $\begin{array}{l}\text { Antibiotics + resistance } \\
\text { modifiers }\end{array}$ & $\mathrm{MIC}\left(\mathrm{mg} \mathrm{l}^{-1}\right)$ & Type of interaction \\
\hline Promethazine (PZ) & 256 & \\
\hline Methylene blue (MB) & 400 & \\
\hline Clomipramine (CP) & 256 & \\
\hline Verapamil (VP) & 1250 & \\
\hline Ampicillin (AMP) & 256 & \\
\hline$+\mathrm{PZ}$ & $\begin{array}{l}\mathrm{AMP}(128)+\mathrm{PZ} \\
(128)\end{array}$ & Additive \\
\hline$+\mathrm{MB}$ & $\begin{array}{l}\mathrm{AMP}(128)+ \\
\mathrm{MB}(50)\end{array}$ & Additive \\
\hline$+\mathrm{CP}$ & $\begin{array}{l}\mathrm{AMP}(128)+\mathrm{CP} \\
(128)\end{array}$ & Additive \\
\hline$+\mathrm{VP}$ & $\begin{array}{l}\text { AMP }(256)+\mathrm{VP} \\
(>1250)\end{array}$ & Indifferent \\
\hline Tetracycline (TET) & 16 & \\
\hline$+\mathrm{PZ}$ & $\begin{array}{l}\text { TET (8) + PZ } \\
\text { (64) }\end{array}$ & Additive \\
\hline$+\mathrm{MB}$ & $\begin{array}{l}\text { TET (8) + MB } \\
(50)\end{array}$ & Additive \\
\hline$+\mathrm{CP}$ & $\begin{array}{l}\text { TET }(8)+\text { CP } \\
(128)\end{array}$ & Additive \\
\hline \multirow[t]{2}{*}{$+\mathrm{VP}$} & TET(4) & Indifferent \\
\hline & $+\mathrm{VP}(>1250)$ & \\
\hline \multicolumn{3}{|l|}{ Erythromycin (ERY) } \\
\hline$+\mathrm{PZ}$ & $\begin{array}{l}\text { ERY (32)+PZ } \\
(128)\end{array}$ & Additive \\
\hline$+\mathrm{MB}$ & $\begin{array}{l}\text { ERY (32)+MB } \\
(50)\end{array}$ & Additive \\
\hline$+\mathrm{CP}$ & $\begin{array}{l}\text { ERY (32)+CP } \\
(128)\end{array}$ & Additive \\
\hline$+\mathrm{VP}$ & $\begin{array}{l}\text { ERY }(64)+V P \\
(>1250)\end{array}$ & Indifferent \\
\hline \multicolumn{3}{|l|}{ Gentamicin (GENT) } \\
\hline$+\mathrm{PZ}$ & $\begin{array}{l}\text { GENT }(0.5)+ \\
\text { PZ (64) }\end{array}$ & Additive \\
\hline$+\mathrm{MB}$ & $\begin{array}{l}\text { GENT }(0.25)+ \\
\text { MB }(25)\end{array}$ & Synergy \\
\hline$+\mathrm{CP}$ & $\begin{array}{l}\text { GENT }(0.25)+ \\
\text { CP }(128)\end{array}$ & Additive \\
\hline$+\mathrm{VP}$ & $\begin{array}{l}\text { GENT }(1)+\text { VP } \\
(>1250)\end{array}$ & Indifferent \\
\hline
\end{tabular}


success when compared to the use of the antibiotic alone [8]. This enhancement of antibiotic activity against selected species of bacteria has been reproduced in vitro with various phenothiazines in combination with gentamicin [8] and other drugs [19].

The mechanism by which phenothiazines, its derivatives, and structurally similar compounds, in enhancing the activity of conventional antibiotics, has been postulated to involve functional alterations of the plasma membrane of bacteria, to the extent that transport mechanisms are affected [5]. The direct action of the phenothiazines on the permeability of the membrane itself has also been considered [20].

$E$. coli, $P$. aeruginosa and $S$. epidermidis are resistant to phenothiazines and its compounds since the concentrations that inhibit growth exceed $60 \mathrm{mg} / 1$ as shown in this and other studies [4,12]. These organisms are well suited for studies of potential enhancement of antibiotic activity by such compounds. The results obtained in this study did not identify any consistent activity of any resistance modifier in any combination with a given antibiotic when challenged against different species of bacteria. The activity of these compounds, at the level of the plasma membrane, is modified by the nature of the cell wall, and thus is species specific. The activity when present, is the result of interaction of the antibiotic and the compound external to the membrane itself. The latter possibility has been proposed by other workers [2]. Synergistic activities demonstrable for a given combination of antibiotic and modifier of antibiotic activity for a species of bacteria may indeed prove clinically useful if such activity is present consistently for strains of that species.

\section{Acknowledgements}

This study was supported by Foundation for Cancer Research of Szeged (Szegedi Rákkutatásért Alapitvány).

\section{References}

[1] Csiszár K, Molnár J. Mechanism of action of tricyclic drugs on Escherichia coli and Yersinia enterocolitica, plasmid maintenance and replication. Anticancer Res 1992;12(Suppl 6b):2267-72.

[2] Gutmann F, Johnson C, Keyzer H, Molnár, J. Charge transfer complexes in microorganisms.. In: Charge Transfer Complexes in Biological Systems. Marcel Dekker Inc, USA, 1997, pp 443488 .

[3] Mischer LA, George GI, Motohashi N. Antibiotics and antimicrobial drugs. In: Smith FD, editor. Handbook of Stereoisomers:
Therapeutic Drugs, Boca Raton, FL: CRC Press, 1989, pp. 199-234

[4] Molnár J, Király J, Mándi Y. Antibacterial action and R-factor inhibiting activity by chlorpromazine. Experientia 1975;31:4448.

[5] Molnár J, Hevér A, Fakla I, Fischer I, Ocsovszki I, Aszalos A. Inhibition of the transport function of membrane proteins by some substituted phenothiazines in E. coli and multidrug resistant tumor cells. Anticancer Res 1997;17(Suppl 1a):481-6.

[6] Amaral L, Kristiansen JE, Abebe LS, Millett W. Inhibition of the respiration of multi-drug resistant clinical isolated of $M y$ cobacterium tuberculosis by thiorizadine: potential use for initial therapy of freshly diagnosed tuberculosis. J Antimicrob Chemother 1996;38(Suppl 6):1049-53.

[7] Chakrabarty AN, Dastidar SG, Annadurai S, Thakurta AG, Ghosh K. Synergism, indifference and antagonism among nonantibiotics, with antibiotics and chemotherapeutic agents. In Chakrabarty AN, Molnár J, Dastidar SG, Motohashi N, editor. Non-Antibiotics. 1998. New Delhi, India: National Institute of Science Communication (NISCOM), pp. 183-200.

[8] Molnár J, Haszon J, Bodrogi T, Martonyi E, Turi S. Synergistic effect of promethazine with gentamicin in frequently recurring pyelonephritis. Int J Urol Nephrol 1990;22(5):405-11.

[9] Rajyaguru JM, Muszynski MJ. Sensitization of Burkholderia cepacia to antibiotics by cationic drugs. J Antimicrob Chemother 1999;41(2):277-80.

[10] Wainwright M, Phoenix DA, Laycock SI, Wareing DR, Whright PA. Photobactericidal activity of phenothiazinium dyes against methicillin-resistant strains of Staphylococcus aureus. FEMS Microbiol Lett 1998;160(Suppl 2):177-81.

[11] Rajyaguru JM, Muszynski MJ. Enhancement of Burkholderia cepacia antimicrobial susceptibility by cation compounds. J Antimicrob Chemother 1997;40(3):345-51.

[12] Farkas S, Molnár J. Elimination of F'lac plasmid different psychotropic drugs and some related compounds. Acta Microbiol Acad Sci Hung 1979;26:351-61.

[13] Triggle DJ. The chemistry of calcium channel agonists and antagonists. In: Born GVR, editor. Handbook of Experimental Pharmacology. Heidelberg: Springer-Verlag, 1988:115-33.

[14] Chakrabarty AN, Dastidar SG, Annadurai S, Thakurta AG, Ghosh K. 1998. Cross-resistance among non antibiotics with respect to themselves and antibiotics. In: Chakrabarty $\mathrm{AN}$, Molnár J, Dastidar SG, and Motohashi N, editor, Non Antibiotics, pp. 201-208.

[15] Kristiansen JE, Amaral L. The potentional management of resistant infection with non-antibiotics. J Antimicrob Chemother 1997;40(3):319-27.

[16] Gunics G, Motohashi N, Farkas S, Molnár J. Effect of some resistance modifiers on the action of ampicillin and erythromycin. J Antimicrob Chemother 1999; 44 (A):87.

[17] Eliopoulos GM, Moellering RC. 1991. Antimicrobial combinations. In: Lorian V, editor. Antibiotics in Laboratory Medicine, 3rd ed., Baltimore, MD, 1991, pp. 434-441.

[18] Alfóldi L, Raskó L, Kerekes E. L-serine determinase of E. coli. J Bacteriol 1968;96:1512-8.

[19] Munoz-Cirado S, Munoz-Bellido JI, Garcia-Rodringuez JA. In vitro activity of non-steroidal anti-inflammatory agents phenothiazines and antidepressants against Brucella species. Eur J Clin Microbial Infect Dis 1996;15(5):418-20.

[20] Endicott JA, Ling V. The biochemistry of P-glycoprotein-mediated multidrug resistance. Ann Rev Biochem 1989;58:137-71. 